\title{
Note \\ PLANT BIOASSAYS TO ASSESS TOXICITY OF TEXTILE SLUDGE COMPOST
}

\author{
Ademir Sérgio Ferreira Araújo'; Regina Teresa Rosim Monteiro* \\ ${ }^{I}$ UESPI - Campus de Parnaíba, Av. Nossa Senhora de Fátima, s/n, 64202-220 - Parnaíba, PI - Brasil. \\ ${ }^{2}$ USP/CENA - Lab. Ecotoxicologia, C.P. 96 - 13400-970 - Piracicaba, SP - Brasil. \\ *Corresponding author <monteiro@cena.usp.br>
}

\begin{abstract}
Composting of industrial wastes is increasing because of recycling requirements set on organic wastes. The evaluation of toxicity of these wastes by biological testing is therefore extremely important for screening the suitability of waste for land application. The toxicity of a textile sludge compost was investigated using seed germination and plant growth bioassays using soybean and wheat. Compost samples were mixed with water (seed germination bioassay) or nutrient solution (plant growth bioassay) at concentrations of 0 , 19, 38, 76 and $152 \mathrm{~g} \mathrm{~L}^{-1}$. No negative effects were observed after five days of compost water-extract in relation to soybean and wheat seed germination. After fifteen days, under a hydroponics system, plant growth had harmful effects of the compost at concentrations above $38 \mathrm{~g} \mathrm{~L}^{-1}$. Textile sludge compost presented great phytotoxicity under hydroponics condition and the soybean and wheat were sensitive for evaluation of organic wastes in plant growth bioassays.
\end{abstract}

Key words: phytotoxicity, seed germination, solid residue, hydroponics

\section{BIOENSAIOS VEGETAIS NA AVALIAÇÃO DA TOXICIDADE DO COMPOSTO DE LODO TÊXTIL}

\begin{abstract}
RESUMO: A compostagem de resíduos industriais tem aumentado devido à pressão para reciclar os resíduos orgânicos. A avaliação da toxicidade destes resíduos por testes biológicos é extremamente importante para selecionar resíduos apropriados para aplicação no solo. A toxicidade do composto de lodo têxtil foi investigada utilizando bioensaios de germinação de sementes e crescimento vegetal em soja e trigo. Amostra do composto foi misturada com água (bioensaio de germinação de sementes) ou solução nutritiva (bioensaio de crescimento de plantas) em concentrações de $0,19,38,76$ e $152 \mathrm{~g} \mathrm{~L}^{-1}$. Não foram observados efeitos negativos, após cinco dias, do extrato aquoso do composto para a germinação de sementes da soja e do trigo. Após quinze dias em sistema hidropônico, houve efeitos deletérios do composto em concentrações acima de $38 \mathrm{~g} \mathrm{~L}^{-1}$. O composto de lodo têxtil mostrou maior fitotoxicidade em condições hidropônicas e a soja e o trigo são espécies sensíveis para avaliação de resíduos orgânicos em bioensaios de crescimento vegetal.

Palavras-chave: fitotoxicidade, germinação de sementes, resíduos sólidos, hidroponia
\end{abstract}

\section{INTRODUCTION}

Industrial waste composting is increasing because of recycling requirements set on organic wastes. Landfilling is also becoming more expensive and industrial companies consequently have to look for cheaper ways of disposing their wastes.

Safety requirements have to be fulfilled if the produced compost is intended for agricultural use and, until now, the harmfulness of solid waste has been estimated mainly on the basis of its chemical composition (Kapanen \& Itavaara, 2001). According to the same authors, limit values are set only for heavy metals, and there are no requirements for the ecotoxicity or chemical levels in composts. Pagga et al. (1996) report that more experience is needed in testing the toxicity of composts before most suitable methods can be suggested or limit values established.

The textile sludge contains organic matter, chemical nutrients and also a relative amount of heavy metals and aromatic dyes (Balan \& Monteiro, 2001). Therefore, the textile sludge must be further composted in order to decrease or eliminate the toxicity before recycling in soils for crop production. In order to ensure that textile sludge composts will be safe for land use, simple methods to evaluate their toxicity, mainly to plants, are necessary. The bioassays of phytotoxicity have received great attention by environmental agencies of the world. Phytotoxicity is described as an intoxication of living plants by substances present in the growth medium, when these substances are taken up and accumulated in plant tissue (Chang et al., 1992). The phytotoxicity effects produced by organic 
wastes are the result of a combination of several factors, like presence of heavy metals, ammonia, salts and low molecular weight organic acids (Zucconi et al., 1985). The evaluation of organic waste toxicity by biological testing is therefore extremely important for screening the suitability of wastes for land application (Fuentes et al., 2004)

Seed germination and plant growth bioassays are the most common techniques used to evaluate compost phytotoxicity (Kapanen \& Itavaara, 2001). A large number of studies have been carried out with different plant species such cucumber and cress (Helfrich et al., 1998), lettuce and soybean (Gundersson et al., 1997), red maple, sugar maple, white pine and pink oak (Maynard, 1998). There are large variations among bioassays and plant species. Itavaara et al. (1997) proposed a lettuce seed germination test in Petri dishes as a potential compost toxicity test and observed that there was a low sensibility of test for compost samples. Fuentes et al. (2004) observed that seed germination has been regarded as a less sensitive method than root length when used as a bioassay for the evaluation of phytotoxicity. Root growth is affected by environmental conditions, such as $\mathrm{pH}$, temperature, salts and metals (Camargo et al., 2004). On the other hand, Kapanen \& Itavaara (2001) recommended a standardized plant test for compost and soil samples. The OECD (1984) recommends the use of several plant species including soybean and wheat for bioassays to evaluate phytotoxicity.

In this study, we compared the seed germination and plant growth bioassays to assess the toxicity of a textile sludge compost.

\section{MATERIAL AND METHODS}

The compost was produced using sludge, obtained from the wastewater treatment system of a textile mill located at Americana, SP, Brazil, using the Beltsville aerated-pile method (USDA, 1980). The composting process lasted for 90 days, and 20 single samples were collected in several sites of the compost mixture, forming a composit sample. The chemical characteristics of the compost are: $\mathrm{pH}, 6.8 ; \mathrm{N}, 0.13 ; \mathrm{K}$, 0.57; P, 0.22; Ca, 1.39; Mg, $0.43 \%$; Cu, 110.8; Zn, 397.0; Cd, <0.3; Cr, 73.9; Ni, 30.44; Pb, 33.4; Mo, $<4.0 \mathrm{mg} \mathrm{kg}^{-1}$. The heavy metal concentration is lower than the maximum permitted concentration (CETESB, 1999).

Two plant bioassays were used to assess the toxicity of this textile sludge compost, described in experiments I and II. In the Experiment I the extracts of the compost were prepared shaking, for $15 \mathrm{~min}$, fresh samples (75\% water content) with distilled water in the following concentrations: $0 \mathrm{~g} \mathrm{~L}^{-1}$ (only water); $19 \mathrm{~g} \mathrm{~L}^{-1}(0.57 \mathrm{~g}$ of compost plus $30 \mathrm{~mL}$ of water); $38 \mathrm{~g} \mathrm{~L}^{-1}$ (1.14 $\mathrm{g}$ of com- post plus $30 \mathrm{~mL}$ of water); $76 \mathrm{~g} \mathrm{~L}^{-1}$ (2.28 $\mathrm{g}$ of compost plus $30 \mathrm{~mL}$ of water) and $152 \mathrm{~g} \mathrm{~L}^{-1}$ (4.56 $\mathrm{g}$ of compost plus $30 \mathrm{~mL}$ of water).

The seed germination bioassay was evaluated according to Tam \& Tiquia (1994). Seeds of soybean (cv. IAC-foscarin) and wheat (cv. IAC-305) were incubated during five days, in the dark. Seed germination, root elongation and germination index (GI, a factor of relative seed germination and relative root elongation) were determined:

Relative seed germination (\%)

$=$ Number of seeds germinated in the extract $\times 100$

Number of seeds germinated in the control

Relative root elongation (\%)

$=$ Mean root elongation in the extract $\times 100$

Mean root elongation in the control

$\mathrm{GI}=\frac{(\% \text { Seed germination }) \times(\% \text { Root elongation })}{100 \%}$

In experiment II the fresh compost was mixed with nutrient solution (Hoagland \& Arnon, 1950) in the following concentrations: $0 \mathrm{~g} \mathrm{~L}^{-1}(1000 \mathrm{~mL}$ of nutrient solution); $19 \mathrm{~g} \mathrm{~L}^{-1}$ (19 $\mathrm{g}$ of compost plus $1000 \mathrm{~mL}$ nutrient solution); $38 \mathrm{~g} \mathrm{~L}^{-1}$ (38 g of compost plus $1000 \mathrm{~mL}$ nutrient solution); $76 \mathrm{~g} \mathrm{~L}^{-1}$ (76 g of compost plus 1000 $\mathrm{mL}$ nutrient solution); $152 \mathrm{~g} \mathrm{~L}^{-1}$ (152 $\mathrm{g}$ of compost plus $1000 \mathrm{~mL}$ nutrient solution).

Soybean (cv. IAC-foscarin) and wheat (cv. IAC305 ) seeds were pre-germinated, on distilled water humidified germination paper, during a period of five days in a germination chamber under controlled conditions (temperature of $25^{\circ} \mathrm{C}$ and photoperiod light and dark of $14 / 10$ h). Plastic pots with capacity of $2 \mathrm{~L}$ were used, each receiving 10 plants distributed in plates of compatible diameter in relation to the superior part of pot. Seedlings were grown, under an aerated hydroponics system, in a greenhouse (temperature of $20^{\circ} \mathrm{C}$ to $28^{\circ} \mathrm{C}$ and environmental photoperiod) adding the concentrations of textile sludge compost. Plants were harvested 15 days after transplanting. Shoot and root length were measured using a ruler, and then dried at $65^{\circ} \mathrm{C}$ for $48 \mathrm{~h}$ for total dry matter measurement.

The compost concentrations used in both bioassays were equal to the application of 19, 38, $76 \mathrm{e} 152 \mathrm{t}$ of compost per ha, corresponding to $1 \mathrm{x}, 2 \mathrm{x}, 4 \mathrm{x}$ and $8 \mathrm{x}$ the amount of nitrogen of compost, respectively, as compared to fertilization of $100 \mathrm{~kg} \mathrm{ha}^{-1} \mathrm{~N}$ (CETESB, 1999).

Treatments were replicated four times in a completely randomized design. Statistical analysis was conducted using the SAS System Software (SAS Institute, 2000). 


\section{RESULTS AND DISCUSSION}

\section{Experiment I}

In general, the increase of compost concentration did not harm seed germination. At all concentrations the percentages of seed germination were greater than $90 \%$ for soybean and wheat (Figure 1a). Compost application resulted in linear increases of root elongation and quadratic increases of the germination index (GI) as shown in Figures $1 \mathrm{~b}$ and $1 \mathrm{c}$. The soybean and wheat seeds presented germination indexes (GI) of $100 \%$ for all the concentrations of compost extract. However, soybean and wheat seeds presented a higher GI for the concentration of $152 \mathrm{~g} \mathrm{~L}^{-1}$, as compared to the other treatments.

The compost did not show inhibitory effects on soybean and wheat. Similar results were found by Fuentes et al. (2004), who observed a germination percentage of more than $70 \%$ for barley and cress seeds in the presence of sewage sludge. In addition, GI values suggest no tox-
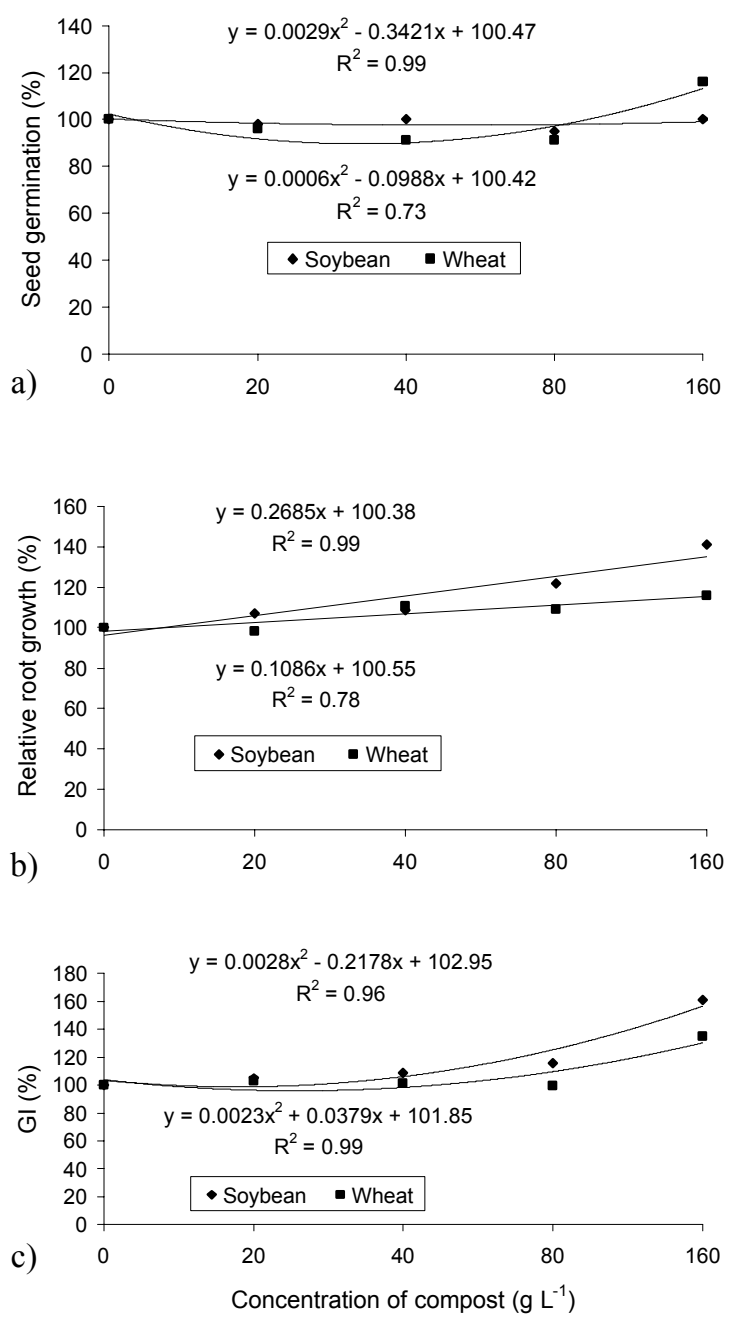

Figure 1 - Percentage of seed germination (a), relative root growth (b) and germination index - GI (c) of soybean and wheat for different concentrations of textile sludge compost. icity of the compost for these plant species. The GI has been proved to be a very sensitive index (Tiquia et al., 1996) indicating, when greater than $80 \%$, the disappearance of the phytotoxicity of the compost.

\section{Experiment II}

The increase of concentrations of compost harmed seedling growth. The application of compost in concentrations equal or above $38 \mathrm{~g} \mathrm{~L}^{-1}$ decreases the total dry matter production, shoot and root length of soybean and wheat seedlings (Figures $2 \mathrm{a}, \mathrm{b}$ and c). Compared to the control, these decreases for soybean were 68 to $76 \%$ for total dry matter, 64 to $81 \%$ to shoot length and 3 to $68 \%$ to root length, and for wheat were 65 to $72 \%$ for total dry matter, 84 to $92 \%$ for shoot length and 46 to $50 \%$ to root length. The application of $19 \mathrm{~g} \mathrm{~L}^{-1}$ of compost did not present negative effects.

The results observed for the hydroponics system indicate that the compost in high concentrations is harm-
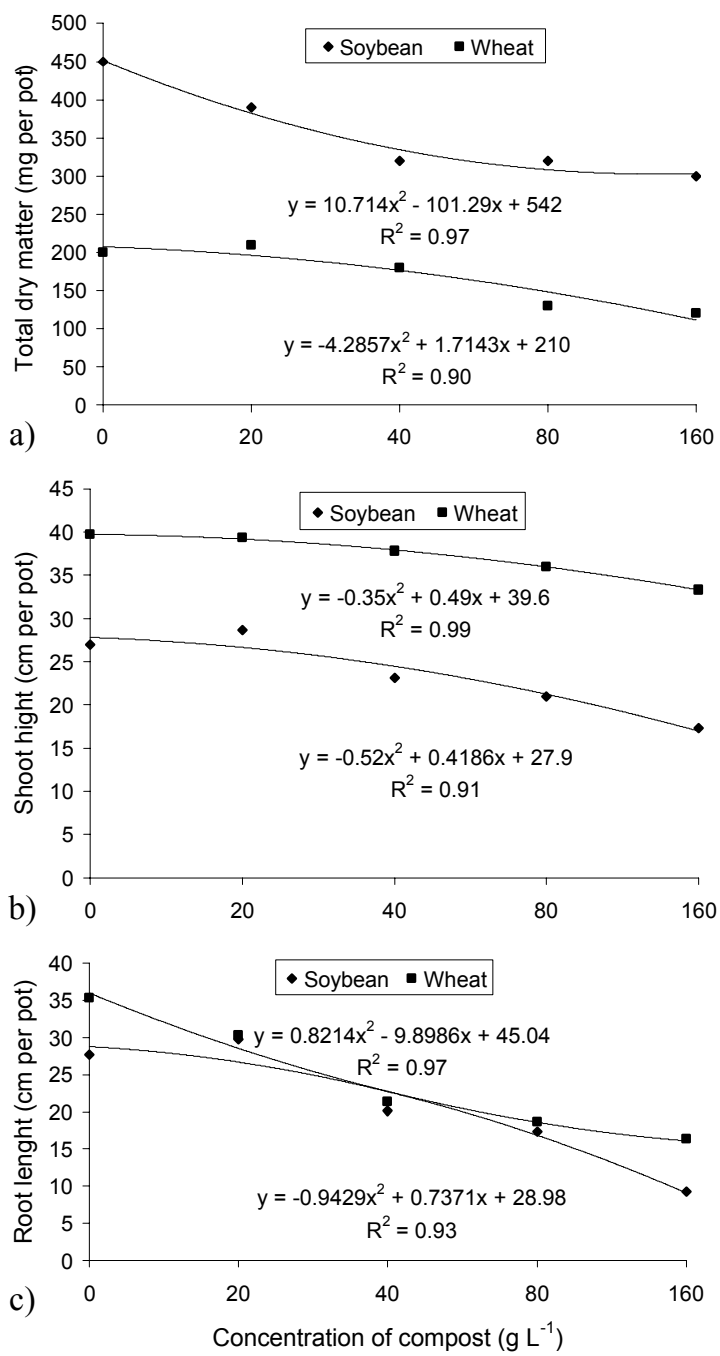

Figure 2 - Total dry matter (a), shoot hight (b) and root length (c) of soybean and wheat seedlings in different concentrations of textile sludge compost, under hydroponics. 
ful to soybean and wheat seedlings, evaluated mainly through total dry matter. According with Kapustka (1997), the total dry matter provides the best indication of an adverse plant response to toxic substances and the decrease in the total dry matter indicates that the application of compost at concentrations equal or above 38 $\mathrm{g} \mathrm{L}^{-1}$ leads to toxic effects to plants, probably by heavy metals present in higher concentration and their bioavailability in the hydroponics solution. However, the concentrations of heavy metals in the compost are lower than the maximum heavy metal concentration for soil application permitted by Cetesb (1999). On the other hand, the bioavailability of heavy metals in hydroponics is higher than in soils, due the interactions among heavy metals and edaphic components (Mcbride et al., 1998). Ali et al. (2004) compared conditions of artificial and natural soils and observed that in the artificial soil a maximum bioavailability of heavy metals is present.

Inhibition was also observed on shoot and root lengths, however, the root length were more affected by the concentrations of the compost. The high decrease in the root length of soybean and wheat indicates that they are more sensitive than the shoot. The roots are the responsible for absorption and accumulation of metals (Marques et al., 2002), therefore metal concentrations affect more the roots than the aerial parts of the plant (Oncel et al., 2000).

Plant growth was a more sensitive parameter than the seed germination in relation to concentrations of the compost extracts. Probably, the great quantity of nutrient reserves in soybean and wheat seed would have lower sensitivity to toxicity of the compost. Cheung et al. (1989) reported that seed of root crops, cereals and legumes containing high quantity of reserves, and the sensitivity of a plant species to toxicity depends on the quantity of their reserves.

In addition, Kapustka (1997) reports that the seed germination bioassay is relatively insensitive to many toxic substances. According to the same author, the insensitivity results from two factors: (a) many chemicals may not be absorbed by the seed, and (b) the embryonic plant draws its nutritional requirements internally from seed stored materials and is effectively isolated from the environment.

On the other hand, the plant growth bioassay overcomes deficiencies of the seed germination bioassays. The duration of the test provides for exposure well into the autotrophic stage of plant development, providing a better approximation of field conditions than root elongation bioassay (Kapustka, 1997). Baca et al. (1990) evaluated the phytotoxicity of compost and observed that plant growth bioassay was more sensitive than seed germination.

\section{CONCLUSIONS}

Textile sludge compost presented great phytotoxicity under hydroponics condition as compared to seed germination and having a possible short-term response.

Textile sludge compost applied at the concentration of $19 \mathrm{~g} \mathrm{~L}^{-1}\left(19 \mathrm{t} \mathrm{ha}^{-1}\right)$ did not induce toxicity in the evaluated plant species.

Soybean and wheat are sensitive plants for the evaluation of the toxicity of organic wastes in plant growth bioassays.

\section{ACKNOWLEDGEMENT}

The authors were supported by personal grant from $\mathrm{CNPq}$.

\section{REFERENCES}

ALI, N.A.; ATER, M.; SUNAHARA, G.I.; ROBIDOUX, P.Y. Phytotoxicity and bioaccumulation of copper and chromium using barley (Hordeum vulgare L.) in spiked artificial and natural forest soils. Ecotoxicology and Environmental Safety, v.57, p.363-374, 2004.

BACA, M.T.; DELGADO, I.C.; SANCHEZ-RAYA, A.J.; GALLARDOLARA, F. Comparative use of cress seed germination and physiological parameters of Helianthus annuus L. to assess compost maturation. Biological Wastes, v.33, p.251-261, 1990.

BALAN, D.S.L.; MONTEIRO, R.T.R. Decolorization of textile indigo dye by lignolytic fungi. Journal of Biotechnology, v.89, p.141-145, 2001.

CAMARGO, C.E.O.; FERREIRA-FILHO, A.W.P.; SALOMON, M.V. Temperature and $\mathrm{pH}$ of nutrient solution on wheat primary root growth. Scientia Agricola, v.61, p.313-318, 2004.

CETESB. Aplicação de biossólidos em áreas agrícolas: critérios para projeto e operação. Norma P4230. São Paulo, 1999.

CHANG, A.C.; GRANTO, T.C.; PAGE, A.L. A methodology for establishing phytotoxicity criteria for chromium, copper, nickel and zinc in agricultural land application of municipal sewage sludges. Environmental Quality, v.21, p.521-536, 1992.

CHEUNG, Y.H.; WONG, M.H.; TAM, N.F.Y. Root and shoot elongation as an assessment of heavy metal toxicity and $\mathrm{Zn}$ equivalent value of edible crops. Hydrobiologia, v.188, p.377-383, 1989.

FUENTES, A.; LlORENS, M.; SAEZ, J.; AGUILAR, M.I.; ORTUÑO, J.F.; MESEGUER, V.F. Phytotoxicity and heavy metals speciation of stabilized sewage sludges. Journal of Hazardous Materials, v.108, p.161-169, 2004.

GUNDERSSON, C.A.; KOSTUK, J.M.; MITCELL, H.G.; NAPOLITANO, G.E.; WICKER, L.F.; RICHMOND, J.E.; STEWART, A.J. Multispecies toxicity assessment of compost produced in bioremediation of an explosives-contaminated sediment. Environmental Toxicology and Chemistry, v.16, p.2529-2537, 1997.

HELFRICH, P.; CHEFETZ, B.; HADAR, Y.; CHEN, Y.; SCHNABL, H. A novel method for determining phytotoxicity in compost. Compost Science and Utilization, v.6, p.6-13, 1998.

HOAGLAND, D.; ARNON, D.I. The water culture method for growing plants without soil. Berkeley: California Agriculture Experiment Station, 1950.

ITAVAARA, M.; VILKMAM, M.; VENELAMPI, O. Windrow composting of biodegradable packaging materials. Compost Science and Utilization, v.5, p.84-92, 1997.

KAPANEN, A.; ITAVAARA, M. Ecotoxicity tests for compost applications. Ecotoxicology and Environmental Safety, v.49, p.1-16, 2001.

KAPUSTKA, L.A. Selection of phytotoxicity tests for use in ecological risk assessments. In: WANG, W.; GORSUCH, J.W.; HUGHES, D. Plants for environmental studies. New York: CRC Press, 1997. p.516548 . 
MARQUES, M.O.; MELO, W.J.; MARQUES, T.A. Metais pesados e o uso de biossólidos na agricultura. In: TSUTIYA, M.T. (Ed.) Biossólidos na agricultura. São Paulo: SABESP, 2002. p.365-403.

MAYNARD, A.A. Utilization of MSW compost in nursery stock production. Compost Science and Utilization, v.6, p.38-44, 1998.

McBRIDE, M.; MARTINEZ, C.E.; SAUVE, S. Copper (II) activity in aged suspensions of geothite and organic matter. Soil Science Society of America Journal, v.62, p.1542-1548, 1998.

ONCEL, I.; KELES, Y.; USTUN, A.S. Interactive effects of temperature and heavy metal stress on the growth and some biochemical compounds in wheat seedlings. Environmental Pollution, v.107, p.315-320, 2000

ORGANIZATION FOR ECONOMIC COOPERATION AND DEVELOPMENT. OECD Guidelines for testing of chemicals. Guideline 208: terrestrial plants, growth test. Paris: OECD, 1984

PAGGA, U.; BEIMBORN, D.B.; YAMAMOTO, M. Biodegradability and compostability of polymers: Test methods and criteria for evaluation. Journal of Environment Polymers Degrading, v.4, p.173-178, 1996. SAS INSTITUTE. System for information. Versão 8.0. Cary: SAS Institute, 2000.
TAM, N.F.Y.; TIQUIA, S.M. Assessing toxicity of 'spent sawdust pig-litter' using seed germination technique. Resource Conservation Recycling, v.11, p.261-274, 1994.

TIQUIA, S.M.; TAM, N.F.Y.; HODGKISS, I.J. Effects of composting on phytotoxicity of spent pig-manure sawdust litter. Environmental Pollution, v.93, p.249-256, 1996.

ZUCCONI, F.; MONACO, A.; FORTE M.; DE BERTOLDI, M. Phytotoxins during the stabilization of organic matter. In: GASSER, J.K.R. (Ed.) Composting of agricultural and other wastes. London: Elsevier, 1985. p.73-86.

USDA. ENVIRONMENTAL PROTETION AGENCY. Manual for composting sewage sludge by the Beltsville aerated-pile method.Washington: EPA, 1980. 65p. (EPA-600/8 80-022).

Received July 02, 2004

Accepted March 29, 2005 